\section{Perennial Ryegrass Allelopathic Potential on Bermudagrass Germination and Seedling Growth}

\author{
Lambert B. McCarty ${ }^{1,4}$, Raymond K. McCauley ${ }^{2}$, Haibo Liu ${ }^{1}$, \\ and F. Wesley Totten ${ }^{2}$ \\ Department of Environmental Horticulture, E-143 Poole Agricultural \\ Center, Clemson University, Clemson, SC 29634-0319
}

Joe E. Toler ${ }^{3}$

Department of Applied Economics and Statistics, 224 Barre Hall, Clemson University, Clemson, SC 29634-0303

Additional index words. inhibitory effect, quadratic response, root ash weight, root length density, root mass density, specific root length

\begin{abstract}
Overseeded perennial ryegrass (Lolium perenne $\mathbf{L}$.) aggressively competes with bermudagrass [Cynodon dactylon (L.) Pers.] for resources and may adversely affect spring transition by releasing allelochemicals into the environment. Growth chamber studies examined germination and growth of 'Arizona Common' bermudagrass in soil amended with $0 \%, 2 \%, 12 \%$, or $23 \%$ perennial ryegrass root or shoot debris or in soil treated with irrigation water in which perennial ryegrass roots at $0,5,10$, or $20 \mathrm{~g} \cdot \mathrm{L}^{-1}$ or shoots at 0,10 , or $20 \mathrm{~g} \cdot \mathrm{L}^{-1}$ had been soaked. Inhibitory effects on bermudagrass germination and growth were most extensive when soil was amended with ryegrass shoot debris, because germination, root ash weight, root length density, and root mass density were reduced $33 \%, 55 \%, 30 \%$, and $52 \%$, respectively. Soil amended with ryegrass root debris only inhibited bermudagrass-specific root length. Application of irrigation water containing either ryegrass root or shoot extracts only inhibited bermudagrass-specific root length. In conclusion, results obtained when soil was amended with shoot debris demonstrated perennial ryegrass can inhibit bermudagrass germination and growth in controlled environments.
\end{abstract}

Overseeding a permanent grass such as bermudagrass with perennial ryegrass complicates spring transition, because perennial ryegrass is usually growing optimally and its upright growth shades the base grass. Although interstand competition between species greatly impacts transition, ryegrass allelopathy has been proposed as another contributing factor. Allelopathy, the suppression of growth of one plant species by another through the release of chemicals into the environment, has been implicated as a mechanism of interference between many plant species. Allelopathic effects of perennial ryegrass on bermudagrass have been suggested but not examined.

Perennial ryegrass has been reported to have inhibitory effects on 'Zenith' zoysiagrass (Zoysia japonica Steud.) (Zuk and Fry, 2006), alfalfa (Medicago sativa L.) (Chung and Miller, 1995), nodding thistle (Carduus nutans L.) (Nicholson et al., 1990), white clover (Trifolium repens L.) (Mattner and Parbery, 2001), and lettuce (Lactuca sativa

\footnotetext{
Received for publication 3 Aug. 2010. Accepted for publication 29 Sept. 2010.

Technical Contribution No. 5868 of the Clemson University Experiment Station.

${ }^{1}$ Professor.

${ }^{2}$ Former Graduate Research Assistant.

${ }^{3}$ Professor Emeritus.

${ }^{4}$ To whom reprint requests should be addressed; e-mail bmccrty@clemson.edu.
}

L.) (Buta et al., 1987). Koski and Newberry (2004) proposed that either intense competition or allelochemicals impeded kentucky bluegrass (Poa pratensis L.) establishment into perennial ryegrass stands at fairway height. Rao and Buta (1983) extracted 19 phenolic compounds from perennial ryegrass that negatively impacted lettuce seed germination. Crabgrass seedling inhibition, chlorosis, and premature death were observed when grown on ryegrass extract tainted agar (King, 1996).

Experiments that monitor indicator species germination and growth in the presence of leachates, extracts, or debris of potential allelopathic agents are acceptable ways of examining and understanding allelopathic potential (Inderjit and Keating, 1999; Inderjit and Weston, 2003). Unequivocally proving allelopathy would require identifying and extracting allelochemicals from perennial ryegrass, applying them to bermudagrass, and observing growth suppression. The chemical basis for inhibitory effects was beyond the scope of this experiment. The objective of this research was to determine if perennial ryegrass contaminated soil media or irrigation water containing perennial ryegrass extracts would inhibit common bermudagrass germination and growth in a controlled environment.

\section{Materials and Methods}

Soil amendment experiments. Studies were conducted to evaluate germination and growth of bermudagrass planted in potting soil amended with perennial ryegrass root or shoot debris. Two identical trials were conducted concurrently for each type of plant material. A blend of 'Icon' (44.6\%), 'Vixen' (34.5\%), and 'Overdrive' (19.5\%) perennial ryegrass pure live seed (PLS) was seeded on 2 Sept. 2007 at a rate of $454 \mathrm{~kg} \cdot \mathrm{ha}^{-1}$ in $52 \times 26$ $\times 6.5-\mathrm{cm}$ flats containing an 85:15 (v/v) sand to peat root mix. The flats were placed in a greenhouse maintained at $\approx 24{ }^{\circ} \mathrm{C}$ day $/ 13{ }^{\circ} \mathrm{C}$ night. Perennial ryegrass was maintained at 5-cm height with handheld clippers, and flats were watered daily with $1.3 \mathrm{~cm}$ of tap water. Beginning 3 weeks after germination, flats were fertilized weekly with water-soluble fertilizer $(16 \mathrm{~N}-2.6 \mathrm{P}-6.6 \mathrm{~K})$ at $350 \mathrm{mg}$ of nitrogen. Perennial ryegrass roots and shoots were harvested after 2 months and cut into $1-\mathrm{cm}$ segments. Twenty-five grams of germination media (Fafard Germination Mix Super Fine; Conrad Fafard, Agawam, MA) containing $60 \%$ Canadian sphagnum peat, $25 \%$ perlite, and $15 \%$ vermiculite were mixed with perennial ryegrass root or shoot tissue at $0 \%$, $2 \%, 12 \%$, or $23 \%$ of soil weight to produce amended soil. A 2.5-cm deep layer of amended soil was placed in $10 \times 10 \times 6$-cm pots containing $37 \mathrm{~g}$ ( $3.5 \mathrm{~cm}$ deep) of non-amended germination media.

On 30 Nov. 2007, 30 'Arizona Common' bermudagrass PLS were placed on the soil surface of each pot, and pots were moved into a growth chamber set at $30{ }^{\circ} \mathrm{C}$ day $/ 25{ }^{\circ} \mathrm{C}$ night with a $16-\mathrm{h}$ photoperiod providing 417 $\mu \mathrm{mol} \cdot \mathrm{m}^{-2} \cdot \mathrm{s}^{-1}$ photosynthetically active radiation $(P A R)$. Pots were watered twice daily with deionized water $\left(5 \mathrm{~mm} \cdot \mathrm{d}^{-1}\right)$. After $24 \mathrm{~d}$, pots were removed from the growth chamber and placed in a cooler at $5{ }^{\circ} \mathrm{C}$ until harvest. Bermudagrass plants were harvested, and seedling number, tiller number, shoot dry weight (SDW), root length density (RLD), root mass density (RMD), specific root length (SRL), and root ash weight (RAW) were recorded. Bermudagrass SDW was obtained by drying the plant tissue in a convection oven at $71{ }^{\circ} \mathrm{C}$ for $72 \mathrm{~h}$ before weighing. Roots were washed to remove germination mix, scanned (Epson Expression 1680; Seiko Epson Corp., Nagano, Japan), and analyzed with WinRhizo root measuring software (Regent Instruments Inc., Quebec, Canada) to determine RLD, RMD, and SRL. After scanning, roots were dried in the convection oven at $71{ }^{\circ} \mathrm{C}$ for $72 \mathrm{~h}$, weighed, placed in a muffle furnace at $700{ }^{\circ} \mathrm{C}$ for $2 \mathrm{~h}$, cooled, and reweighed. RAW was obtained by subtracting muffle furnace weight from convection oven weight. Soil from the surface $2.5 \mathrm{~cm}$ of each pot was collected and tested for salinity level and macro- and micronutrients.

Irrigation solution experiments. Studies were conducted to evaluate bermudagrass germination and growth when irrigated with deionized water in which perennial ryegrass roots or shoots had been soaked. A blend of 'Icon' (44.6\%), 'Vixen' (34.5\%), and 'Overdrive' (19.5\%) perennial ryegrass PLS was seeded on $10 \mathrm{Jan} .2008$ at a rate of $454 \mathrm{~kg} \cdot \mathrm{ha}^{-1}$ in $52 \times 26 \times 6.5$-cm flats containing an 85:15 
$(\mathrm{v} / \mathrm{v})$ sand to peat root mix. The flats were placed in a greenhouse maintained at $\approx 24{ }^{\circ} \mathrm{C}$ day $/ 13{ }^{\circ} \mathrm{C}$ night. The perennial ryegrass was maintained at $5-\mathrm{cm}$ height for 2 months with handheld clippers. Flats were watered daily with $1.3 \mathrm{~cm}$ of tap water and fertilized weekly, starting 2 weeks after germination, with a soluble fertilizer $(16 \mathrm{~N}-2.6 \mathrm{P}-6.6 \mathrm{~K})$ at $350 \mathrm{mg}$ of nitrogen. After 2 months, perennial ryegrass roots and shoots were harvested and cut into $1-\mathrm{cm}$ segments. Tissue segments were added to deionized water in 2.0-L plastic containers to provide $0,5,10$, or $20 \mathrm{~g} \cdot \mathrm{L}^{-1}$ of root tissue or 0,10 , or $20 \mathrm{~g} \cdot \mathrm{L}^{-1}$ of shoot tissue. After $48 \mathrm{~h}$, the solution was screened and vacuum-filtered of debris and stored in a cooler at $5{ }^{\circ} \mathrm{C}$ to serve as irrigation solution for bermudagrass seedlings.

On 17 Mar. $2008,10 \times 10 \times 9$-cm pots were filled with the same germination mix used in the soil amendment experiments and saturated with $300 \mathrm{~mL}$ of a randomly assigned irrigation solution. Twenty 'Arizona Common' bermudagrass PLS were placed on the potting soil of each pot, placed in a growth chamber set at $30^{\circ} \mathrm{C}$ day $/ 25^{\circ} \mathrm{C}$ night with a 16 -h photoperiod providing $331 \mu \mathrm{mol} \cdot \mathrm{m}^{-2} \cdot \mathrm{s}^{-1}$ $P A R$ for $35 \mathrm{~d}$, and irrigated daily with $30 \mathrm{~mL}$ of assigned irrigation solution. Pots were removed on 21 Apr. 2008 and placed in a cooler at $5{ }^{\circ} \mathrm{C}$ until seedlings were harvested. Samples of each irrigation solution concentration were analyzed for macro- and micronutrients, $\mathrm{pH}$, and conductivity. The same data collected in the soil amendment studies were also obtained in these studies to examine the effects of irrigation solutions containing ryegrass plant extracts on bermudagrass germination and growth.

Statistical design and analysis. Soil amendment and irrigation solution experiments were conducted in completely randomized designs with four replications; root and shoot tissue trial was repeated concurrently. All experiments were factorials consisting of two plant tissue types and three or four tissue concentrations. Data were analyzed using the Statistical Analysis System (SAS Institute, 2006) general linear model procedure. No treatment $\times$ trial interaction was detected for soil amendment or irrigation solution experiments, so results of the repeated trials were combined. Analysis of variance was performed to evaluate main and interactions effects of plant tissue types and concentrations using $\alpha=0.05$. Orthogonal polynomial contrasts were used to examine the effect of tissue concentration on bermudagrass germination and growth using $\alpha=0.05$.

\section{Results and Discussion}

Soil amendment experiments. Interaction between plant tissue type and concentration was detected $(P<0.05)$ for all bermudagrass response variables, so results are presented and discussed separately for root and shoot tissue.

Soil amended with perennial ryegrass root tissue did not affect bermudagrass germination, tillering, or RLD (Table 1; $P>0.05$, all contrasts). However, there was evidence of perennial ryegrass inhibitory effects for SDW and SRL and stimulatory effects for RAW and RMD. SDW declined as root amendment level increased from $0 \%$ to $12 \%$ but then increased at the highest amendment level $(P<$ 0.05 , quadratic contrast). A possible explanation is that the highest amendment level provided sufficient additional nutrition to enhance shoot growth and thus mask perennial ryegrass-inhibitory effects. Increased organic acids could also be associated with higher amendment levels, which could bind allelochemicals. A linear decline in SRL was detected as root tissue amendment levels increased $(P<$ 0.05 , linear contrast), whereas RAW and RMD increased linearly $(P<0.05$, linear contrasts). Compared with the control, the $23 \%$ amendment level decreased SRL by $38 \%$ but increased RAW and RMD by $138 \%$ and $41 \%$, respectively. Lower SRL indicates short, stubby roots, whereas a high SRL indicates thin, highly branched roots similar to that observed with turf grown under low light conditions (Jiang et al., 2004).

Zuk and Fry (2006) found that germination and all growth measures (except root length in one study) were inhibited when zoysiagrass was grown in soil amended with perennial ryegrass roots. However, they also observed instances, similar to SDW in this study, in which lower levels of ryegrass tissue produced inhibitory effects, whereas the highest level was similar to the control.

The highest incidence of inhibitory effects on bermudagrass germination and growth was observed when soil was amended with perennial ryegrass shoot tissue (Table 2). Shoot-amended soil affected bermudagrass germination as shoot numbers decreased linearly with increased amendment level $(P<$ 0.05 , linear contrast); however, SDW was unaffected by amendment level $(P>0.05$, all contrasts). Less competition for resources when fewer shoots are present could enhance shoot growth and explain why SDW did not change as amendment level increased. Tillering increased as concentration of perennial ryegrass shoot tissue increased to $12 \%$ but then declined for the highest concentration $(P<0.05$, quadratic contrast). Stimulatory responses at lower rates and inhibitory effects at higher rates have been observed for centipedegrass [Eremochloa ophiuroides (Munro) Hack] debris on hairy vetch (Vicia villosa Roth) (White et al., 1989) and for crimson clover [Triflorium incarnarum (L.)] on morning glory (Ipomea spp.) (Inderjit and Keating, 1999). Perennial ryegrass-inhibitory effects were also detected for RAW, RLD, and RMD $(P<0.05$, linear contrasts). Compared with the control, RAW, RLD, and RMD were reduced $55 \%, 30 \%$, and $52 \%$, respectively, when grown in soil amended with $23 \%$ ryegrass shoot tissue. However, in contrast to results obtained with perennial ryegrass rootamended soil, SRL was unaffected by shootamended soil.

Irrigation solution experiments. Results for perennial ryegrass irrigation solution studies differed from the soil amendment studies, because considerably less evidence of bermudagrass inhibition was observed. However, because interaction between plant tissue type and concentration was detected $(P<0.05)$ for most bermudagrass response variables, results are presented and discussed separately for root and shoot tissue studies.

The only evidence of inhibitory effects provided by irrigation solutions containing perennial ryegrass root extracts was observed for bermudagrass SRL that declined linearly as root extract concentration increased (Table 3; $P<0.05$, linear contrast). Bermudagrass

Table 1. Bermudagrass germination and growth in perennial ryegrass root-amended soil.

\begin{tabular}{|c|c|c|c|c|c|c|c|}
\hline $\begin{array}{l}\text { Amendment } \\
(\%)\end{array}$ & $\begin{array}{l}\text { Shoot }^{z} \\
\text { (no.) }\end{array}$ & $\begin{array}{l}\text { Tiller } \\
\text { (no.) }\end{array}$ & $\begin{array}{c}\text { Shoot dry } \\
\text { wt (g) }\end{array}$ & $\begin{array}{c}\text { Root ash } \\
\text { wt (g) }\end{array}$ & $\begin{array}{c}\text { Root length } \\
\text { density }\left(\mathrm{cm} \cdot \mathrm{m}^{-3}\right)\end{array}$ & $\begin{array}{c}\text { Root mass } \\
\text { density }\left(\mathrm{g} \cdot \mathrm{cm}^{-3}\right)\end{array}$ & $\begin{array}{c}\text { Specific root } \\
\text { length }\left(\mathrm{cm} \cdot \mathrm{g}^{-1}\right)\end{array}$ \\
\hline 0 & 21.9 & 25.8 & 0.24 & 0.13 & 5.27 & $2.16 \mathrm{E}-4$ & 24,200 \\
\hline 2 & 22.3 & 26.6 & 0.23 & 0.12 & 4.26 & $1.89 \mathrm{E}-4$ & 23,800 \\
\hline 12 & 22.1 & 24.7 & 0.19 & 0.18 & 4.44 & $2.39 \mathrm{E}-4$ & 20,300 \\
\hline 23 & 24.9 & 26.3 & 0.34 & 0.31 & 4.52 & $3.05 \mathrm{E}-4$ & 15,000 \\
\hline \multicolumn{8}{|c|}{ Polynomial contrast } \\
\hline Linear & NS & NS & $*$ & * & NS & * & $*$ \\
\hline Quadratic & NS & NS & $*$ & NS & NS & NS & NS \\
\hline Cubic & NS & NS & NS & NS & NS & NS & NS \\
\hline
\end{tabular}

${ }^{\mathrm{z}}$ Mean number of seed germinated (30 pure live seed seed planted per replication).

NS, *Nonsignificant, significant at $P \leq 0.05$.

Table 2. Bermudagrass germination and growth in perennial ryegrass shoot-amended soil.

\begin{tabular}{|c|c|c|c|c|c|c|c|}
\hline $\begin{array}{l}\text { Amendment } \\
(\%)\end{array}$ & $\begin{array}{l}\text { Shoot }^{z} \\
\text { (no.) }\end{array}$ & $\begin{array}{l}\text { Tiller } \\
\text { (no.) }\end{array}$ & $\begin{array}{c}\text { Shoot dry } \\
\text { wt (g) }\end{array}$ & $\begin{array}{l}\text { Root ash } \\
\text { wt (g) }\end{array}$ & $\begin{array}{c}\text { Root length } \\
\text { density }\left(\mathrm{cm} \cdot \mathrm{m}^{-3}\right)\end{array}$ & $\begin{array}{c}\text { Root mass } \\
\text { density }\left(\mathrm{g} \cdot \mathrm{cm}^{-3}\right)\end{array}$ & $\begin{array}{c}\text { Specific root } \\
\text { length }\left(\mathrm{cm} \cdot \mathrm{g}^{-1}\right)\end{array}$ \\
\hline 0 & 24.5 & 26.0 & 0.23 & 0.11 & 4.38 & $1.78 \mathrm{E}-4$ & 26,000 \\
\hline 2 & 22.1 & 26.8 & 0.22 & 0.09 & 4.29 & $1.45 \mathrm{E}-4$ & 26,300 \\
\hline 12 & 19.1 & 28.9 & 0.26 & 0.08 & 3.94 & $1.39 \mathrm{E}-4$ & 24,400 \\
\hline 23 & 16.3 & 23.5 & 0.21 & 0.05 & 3.05 & 0.86 E-4 & 28,900 \\
\hline \multicolumn{8}{|c|}{ Polynomial contrast } \\
\hline Linear & $*$ & NS & NS & $*$ & $*$ & $*$ & NS \\
\hline Quadratic & NS & $*$ & NS & NS & NS & NS & NS \\
\hline Cubic & NS & NS & NS & NS & NS & NS & NS \\
\hline
\end{tabular}

${ }^{\mathrm{z}}$ Mean number of seed germinated (30 pure live seed planted per replication).

NS, *Nonsignificant, significant at $P \leq 0.05$. 
germination and RLD were unaffected by the level of root extracts in the irrigation solution ( $P>0.05$, all contrasts). However, tillering, SDW, RAW, and RMD were stimulated by the concentration of root tissue extracts in the irrigation solution and exhibited linear increases $(P<0.05$, linear contrasts). A plausible explanation is the amount of nutrients that leaked from root tissue, whereas soaking would increase as tissue concentration increased and result in enhanced bermudagrass growth. Soil assays support this premise, because soil nitrate levels increased as the amount of soaked root tissue increased (data not shown). Stimulation of growth resulting from increased nitrate levels could mask inhibitory effects of perennial ryegrass allelochemicals. In contrast, Zuk and Fry (2006) reported reduced germination and growth of zoysiagrass irrigated with solutions in which perennial ryegrass roots were soaked.

Irrigation solutions containing leachates from soaked perennial ryegrass shoots stimulated bermudagrass germination and tillering, because shoot and tiller numbers linearly increased with concentration of soaked tissue (Table 4; $P<0.05$, linear contrast). The only bermudagrass response that declined as concentration of soaked shoot tissue increased was SRL $(P<0.05$, linear contrast). SDW, RAW, RLD, and RMD exhibited curvilinear response patterns because mean values increased with $10 \mathrm{~g} \cdot \mathrm{L}^{-1}$ but then declined for the highest tissue concentration $(P<0.05$, quadratic contrasts). A quadratic response was observed once in the soil amendment experiments and has been reported in other soil amendment studies (Inderjit and Keating, 1999; White et al., 1989). Reductions in bermudagrass growth response at the highest tissue concentration may be attributable to increased competition for resources and/or increased amounts of allelochemical leachates. Lickfeldt et al. (2001) evaluated several cool-season turfgrass species for allelopathic activity and observed greater shoot yields for some recipient species when they received leaf extract irrigation solutions compared with the deionized control and attributed the increased yield to nutrients that leaked from soaked leaves providing a fertilizing effect. Zoysiagrass seedling emergence and root mass were reduced by $60 \%$ and $66 \%$, respectively, when irrigated with solutions in which perennial ryegrass shoots were soaked (Zuk and Fry, 2006).

Zuk and Fry (2006) suggested zoysiagrass seedling inhibition and impairment by tainted irrigation solutions was an allelopathic effect because the irrigation solutions possessed low salinity. In the present study, no nutrient imbalance of calcium, phosphorous, or soil salinity stress levels were detected; however, soil nitrate nitrogen levels were generally in the insufficient range (Table 5), which is typical for most soils. Perennial ryegrass plant maturity at harvest may impact its potential for inhibiting bermudagrass germination and growth. Lickfeldt et al. (2001) conjectured that the 23-d study may not have provided sufficient time for allelochemicals to accumulate in the root zone and negatively affect bermudagrass growth. The effect of perennial ryegrass extract on duckweed (Lemna minor L.) fronds was dependent on concentration and sampling date (King, 1996). Bertin et al. (2003) observed that fine fescue (Festuca rubra L.) seedlings exuded large quantities of bioactive root matter into the agar medium, but older fine fescue plants had a more profound effect on test species. Considering overseeded perennial ryegrass would usually be

Table 3. Bermudagrass germination and growth when irrigation solution containing perennial ryegrass root extracts was applied.

\begin{tabular}{|c|c|c|c|c|c|c|c|}
\hline $\begin{array}{l}\text { Extract } \\
\left(\mathrm{g} \cdot \mathrm{L}^{-1}\right)\end{array}$ & $\begin{array}{l}\text { Shoot }^{2} \\
\text { (no.) }\end{array}$ & $\begin{array}{l}\text { Tiller } \\
\text { (no.) }\end{array}$ & $\begin{array}{c}\text { Shoot dry } \\
\text { wt (g) }\end{array}$ & $\begin{array}{c}\text { Root ash } \\
\text { wt (g) }\end{array}$ & $\begin{array}{c}\text { Root length } \\
\text { density }\left(\mathrm{cm} \cdot \mathrm{m}^{-3}\right)\end{array}$ & $\begin{array}{c}\text { Root mass } \\
\text { density }\left(\mathrm{g} \cdot \mathrm{cm}^{-3}\right)\end{array}$ & $\begin{array}{c}\text { Specific root } \\
\text { length }\left(\mathrm{cm} \cdot \mathrm{g}^{-1}\right)\end{array}$ \\
\hline 0 & 10.4 & 17.6 & 0.29 & 0.18 & 2.75 & $2.78 \mathrm{E}-4$ & 9,800 \\
\hline 5 & 11.9 & 22.9 & 0.42 & 0.19 & 2.87 & $3.23 \mathrm{E}-4$ & 9,400 \\
\hline 10 & 10.5 & 22.8 & 0.41 & 0.17 & 2.39 & $2.90 \mathrm{E}-4$ & 8,800 \\
\hline 20 & 12.9 & 32.3 & 0.75 & 0.26 & 2.87 & 4.39 E-4 & 7,800 \\
\hline \multicolumn{8}{|c|}{ Polynomial contrast } \\
\hline Linear & NS & $*$ & * & * & NS & $*$ & $*$ \\
\hline Quadratic & NS & NS & NS & NS & NS & NS & NS \\
\hline Cubic & NS & NS & NS & NS & NS & NS & NS \\
\hline
\end{tabular}

${ }^{\mathrm{z}}$ Mean number of seed germinated (20 pure live seed planted per replication).

Ns, *Nonsignificant, significant at $P \leq 0.05$.

Table 4. Bermudagrass germination and growth when irrigation solution containing perennial ryegrass shoot extracts was applied.

\begin{tabular}{|c|c|c|c|c|c|c|c|}
\hline $\begin{array}{l}\text { Extract } \\
\left(\mathrm{g} \cdot \mathrm{L}^{-1}\right)\end{array}$ & $\begin{array}{l}\text { Shoot }^{\mathrm{z}} \\
\text { (no.) }\end{array}$ & $\begin{array}{l}\text { Tiller } \\
\text { (no.) }\end{array}$ & $\begin{array}{l}\text { Shoot dry } \\
\text { wt (g) }\end{array}$ & $\begin{array}{c}\text { Root ash } \\
\text { wt (g) }\end{array}$ & $\begin{array}{c}\text { Root length } \\
\text { density }\left(\mathrm{cm} \cdot \mathrm{m}^{-3}\right)\end{array}$ & $\begin{array}{c}\text { Root mass } \\
\text { density }\left(\mathrm{g} \cdot \mathrm{cm}^{-3}\right)\end{array}$ & $\begin{array}{c}\text { Specific root } \\
\text { length }\left(\mathrm{cm} \cdot \mathrm{g}^{-1}\right)\end{array}$ \\
\hline 0 & 10.6 & 20.6 & 0.32 & 0.16 & 2.52 & $2.60 \mathrm{E}-4$ & 9,500 \\
\hline 10 & 12.6 & 38.7 & 1.12 & 0.33 & 3.08 & $5.63 \mathrm{E}-4$ & 6,300 \\
\hline 20 & 14.2 & 36.4 & 0.91 & 0.25 & 2.66 & 4.17 E-4 & 6,900 \\
\hline \multicolumn{8}{|c|}{ Polynomial contrast } \\
\hline Linear & * & $*$ & * & NS & NS & NS & $*$ \\
\hline Quadratic & NS & NS & * & * & $*$ & $*$ & NS \\
\hline
\end{tabular}

${ }^{\mathrm{z}}$ Mean number of seed germinated (20 pure live seed planted per replication).

Ns, *Nonsignificant, significant at $P \leq 0.05$.
Table 5. Nitrate concentration of soil-less media when irrigated with solution containing either perennial ryegrass shoot or root extracts.

\begin{tabular}{|c|c|c|}
\hline \multirow{3}{*}{$\begin{array}{l}\text { Extract } \\
\left(\mathrm{g} \cdot \mathrm{L}^{-1}\right)\end{array}$} & \multicolumn{2}{|c|}{$\mathrm{NO}_{3}$ concn } \\
\hline & Shoot & Root \\
\hline & \multicolumn{2}{|c|}{ (ppm) } \\
\hline 0 & 0 & 7 \\
\hline 5 & - & 7 \\
\hline 10 & 9 & 12 \\
\hline 20 & 66 & 26 \\
\hline
\end{tabular}

established for several months before bermudagrass breaks dormancy, there would be ample time for the potential accumulation of allelochemicals.

In addition to resource competition and allelopathy, other potential contributing factors have been proposed by some researchers to explain interference between plant species. Zuk and Fry (2006) speculated that the high salinity of soil amended with perennial ryegrass leaves may have hampered zoysiagrass seedling emergence and growth. Gannon et al. (2006) credited soil nitrate depression from elevated $\mathrm{C}: \mathrm{N}$ ratios of centipedegrass debris for the reduction in radical and shoot weights of targeted species.

In conclusion, severed perennial ryegrass shoots provided the strongest evidence of bermudagrass germination and growth inhibition that may be attributable to allelochemicals. Although Zuk and Fry (2006) reported inhibitory effects on zoysiagrass germination and growth regardless of perennial ryegrass tissue source or method of treatment, they observed the greatest reductions when soil was amended with severed ryegrass leaves. Rice (1974) concluded that allelochemicals are more potent and concentrated in shoot tissue, but they most likely act through the soil. Lickfeldt et al. (2001), however, proposed that raw plant material is not the source of allelochemicals but that decomposition of plant tissue by micro-organisms in the thatch layer produces allelochemicals. Our study demonstrated that perennial ryegrass can inhibit bermudagrass germination and growth in controlled environments, but additional experimentation will be necessary to further elucidate the impact of allelopathy when perennial ryegrass is overseeded into existing bermudagrass.

\section{Literature Cited}

Bertin, C., X. Yang, and L.A. Weston. 2003. The role of root exudates and allelochemicals in the rhizosphere. Plant Soil 256:67-83.

Buta, J.G., D.W. Spaulding, and A.N. Reed. 1987. Differential growth responses of fractionated turfgrass seeds and leachates. HortScience 22: 1317-1319.

Chung, I.-M. and D.A. Miller. 1995. Allelopathic influence of nine forage grass extracts on germination and seedling growth of alfalfa. Agron. J. 87:767-772.

Gannon, T.W., F.H. Yelverton, and J.S. McElroy. 2006. Allelopathic potential of centipedegrass (Eremochloa ophiuroides). Weed Sci. 54:521525 .

Inderjit, and K.I. Keating. 1999. Allelopathy: Principles, procedures, processes, and promises 
for biological control. Adv. Agron. 67:141231.

Inderjit, and L.A. Weston. 2003. Root exudation: An overview, p. 235-250. In: De Kroon, H. and E.J.W. Visser (eds.). Root ecology. SpringerVerlag, Heidelberg, Germany.

Jiang, Y., R.R. Duncan, and R.N. Carrow. 2004. Assessment of low light tolerance of seashore paspalum and bermudagrass. Crop Sci. 44: 587-594.

King, J. 1996. Allelopathy vs. Acremonium endophytes vs. competition effect on crabgrass suppression by 12 perennial ryegrasses. Turfgrass Environ. Res. Summ. 52-54.
Koski, T. and J. Newberry. 2004. Conversion of ryegrass fairways to bluegrass: Impossible dream? USGA Green Sec. Rec. 42:6-7.

Lickfeldt, D.W., T.B. Voigt, B.E. Branham, and T.W. Fermanian. 2001. Evaluation of allelopathy in cool season turfgrass species. Intl. Turfgrass Soc. 9:1013-1018.

Mattner, S.W. and D.G. Parbery. 2001. Rust-enhanced allelopathy of perennial ryegrass against white clover. Agron. J. 93:54-59.

Nicholson, K.S., A. Rahman, and D.A. Wardle. 1990. Interactions between establishing nodding thistle and pasture seedlings. Proc. 43rd New Zealand Weed and Pest Control Conf. 43:225-228.
Rao, M.M. and J.G. Buta. 1983. Growth inhibitors from grasses: HPLC of phenolics. Proc. 10th Annu. Mtg. Plant Growth Regulat. Soc. Amer 10:43-48.

Rice, E.L. 1974. Allelopathy. Academic Press, New York, NY.

SAS Institute. 2006. SAS user's guide: Statistics. SAS Inst., Cary, NC.

White, R.H., A.D. Worsham, and U. Blum. 1989. Allelopathic potential of legume debris and aqueous extracts. Weed Sci. 37:674-679.

Zuk, A.J. and J.D. Fry. 2006. Inhibition of 'Zenith' zoysiagrass seedling emergence and growth by perennial ryegrass leaves and roots. HortScience 41:818-821. 